\title{
TREATMENT OF WASTEWATER FROM SEPARATORS FOR RAINFALL RUNOFF USING ELECTROCHEMICAL OXIDATION PROCESSES
}

\author{
Morana Drušković ${ }^{*}$, Dražen Vouk ${ }^{2}$, Mario Šiljeg ${ }^{3}$, Krešimir Maldini ${ }^{4}$, \\ ${ }^{1}$ Dok-Ing Energo d.o.o., Slavonska avenija 22G, 10000 Zagreb, Croatia \\ ${ }^{2}$ University of Zagreb, Faculty of Civil Engineering, Water Research Department, Kačićeva 26, 10000 Zagreb, \\ Croatia \\ ${ }^{3}$ Ministry of Economy and Sustainable Development, Radnička cesta 80, 10000 Zagreb, Croatia \\ ${ }^{4}$ Hrvatske vode, Main Water Management Laboratory, City Street Vukovara 220, 10000 Zagreb, Croatia \\ *E-mail of corresponding author: morana.druskovic@gmail.com
}

\begin{abstract}
In recent years, industry has increased and with it the amount of oily wastewater, which are considered hazardous waste because they contain various types of heavy metals and oils that endanger the environment and human health. In the last twenty years, there has been increased research on new technologies to treat wastewater as efficiently and environmentally friendly as possible. A recent approach to wastewater treatment is the application of electrochemical processes such as the electro-Fenton process, which belongs to the group of electrochemical advanced oxidation processes and electrocoagulation. The aim of this work was to remove organic contaminants and heavy metals from wastewater originating from oil and grease separators that clean stormwater runoff from traffic areas. The use of stainless steel, iron and aluminum electrodes results in electrooxidation, electroreduction and electrocoagulation. At a current of $15 \mathrm{~A}$ the treatment efficiency was $50 \%$ for COD and $73 \%$ for mineral oil. At a current of 110 A the treatment efficiency was $96 \%$ for COD and $90 \%$ for mineral oil.
\end{abstract}

Keywords: electrochemical advanced oxidation processes, electrocoagulation, rainfall runoff, separators, mineral oil, COD, heavy metals

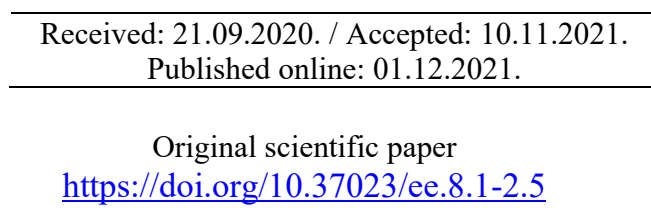

\section{INTRODUCTION}

Wastewater is water that has changed its original composition through the introduction of pollutants whose presence causes a change in the physical, biological, chemical, or bacteriological properties of the water, and therefore it cannot be used in agriculture or for other purposes (Jurac, 2009). Oily wastewater is defined as a combination of wastewater and oil in some ratio and is usually the product of oil refining, pet-rochemicals refining, metallurgical industries, and marine products. Oil and grease should be removed from wastewater before reuse or discharge to the environment to reduce adverse impacts on human health, groundwater, soil, air, and the environment. Oil includes light and heavy hydrocarbons, oil, tar, grease, wax, soap and more. The oil in wastewater can be of mineral, animal, or plant origin. In terms of their physical properties, they are classified into 4 categories - free oils, dispersed oils, emulsified oils and dissolved oils. Oil-containing water is mostly in emulsified form. This form differs from the dispersed solution mainly in the stability of the form. This improved stability is influenced by substances - emulsifiers - located at the oil-water interface (CocaPrados et al., 2011).

An important activity in sustainable water management is wastewater treatment. The wastewater is treated so that it can be reused or discharged into water bodies or soil. There are many known and devel-oped technologies that aim to achieve a certain quality of treated water. The most used treatment technol-ogies are chemical coagulation, flotation, and electrocoagulation. In addition, some hybrid processes have been developed - processes that consist of a combination of two or more treatment processes (Coca-Parados et al., 2011).

\section{ELECTROCHEMICAL ADVANCED OXIDATION PROCESSES}

Electrochemical advanced oxidation processes (EAOP) belong to the group of advanced oxidation processes (AOP) most used in wastewater treatment with high concentrations of organic pollutants. One of the most used EAOPs is the electro-Fenton process (EF), which is a combination of Fenton reagent chemistry and electrochemistry (Brillas 2014; Grymonpre et al. 2004). Indirect anodic oxidation or electro-Fenton process results in the 
oxidation of organics using chlorine, hypochlorite, hydrogen peroxide, and ozone, which are electrochemically generated and reactive. The EF process is described in detail by the following reactions (Oturan N. and Oturan M.A., 2018).

$$
\begin{aligned}
& \text { Anode: } \\
& 2 \mathrm{Cl}^{-} \rightarrow \mathrm{Cl}_{2}+2 \mathrm{e}^{-} \\
& 6 \mathrm{HOCl}+3 \mathrm{H}_{2} \mathrm{O} \rightarrow 2 \mathrm{ClO}_{3}^{-}+4 \mathrm{Cl}^{-}+1.5 \mathrm{O}_{2}+6 \mathrm{e}^{-} \\
& 2 \mathrm{H}_{2} \mathrm{O} \rightarrow \mathrm{O}_{2}+4 \mathrm{H}++4 \mathrm{e}^{-}
\end{aligned}
$$

Summary reaction:

$$
\begin{aligned}
& \mathrm{Cl}_{2}+\mathrm{H}_{2} \mathrm{O} \rightarrow \mathrm{HOCl}+\mathrm{H}^{+}+\mathrm{Cl}^{-} \\
& \mathrm{HOCl} \rightarrow \mathrm{H}^{+}+\mathrm{OCl}^{-} \\
& \text {Cathode: } \\
& 2 \mathrm{H}_{2} \mathrm{O}+2 \mathrm{e}^{-} \rightarrow 2 \mathrm{OH}^{-}+\mathrm{H}_{2} \\
& \mathrm{OCl}^{-}+\mathrm{H}_{2} \mathrm{O}+2 \mathrm{e}^{-} \rightarrow \mathrm{Cl}^{-}+2 \mathrm{OH}^{-}
\end{aligned}
$$

Indirect anodic oxidation of organic components using iron electrodes leads to the formation of hydroxyl radicals in the EF reaction consisting of electrochemically generated $\mathrm{Fe}^{2+}$ and hydrogen peroxide (H2O2) according to the reaction (Orescanin et al., 2012).

$$
\mathrm{Fe}^{2+}+\mathrm{H}_{2} \mathrm{O}_{2} \rightarrow \mathrm{Fe}^{3+}+\cdot \mathrm{OH}+\mathrm{OH}^{-}
$$

Electrocatalytic regeneration of $\mathrm{Fe}^{2+}$ ions to $\mathrm{Fe}^{3+}$ ions allows $\mathrm{Fe}^{3+}$ ions to be reused as a catalyst, thus avoiding the formation of large amounts of iron hydroxide sludge (Monteil et al., 2018).

$$
\mathrm{Fe}^{2+}+\cdot \mathrm{OH} \rightarrow \mathrm{Fe}^{3+}+\mathrm{OH}^{-}
$$

\section{ELEKTROCOAGULATION}

The process of electrocoagulation (EC) is based on the passage of electric current through electrodes in the reactor and immersed in water, which with their dissolved particles (coagulants) dissolve and neutralize the charges of the dispersed (dirt) particles. Such a destabilization process is called coagulation. In flocculation, the destabilized or coagulated particles accumulate into larger clusters (flocs) which separate from the mixture by precipitation. In worldwide practice, iron or aluminum electrodes are mainly used.

In the process of electrocoagulation, several electrochemical reactions take place simultaneously at the an-ode and the cathode. The action of direct current on the electrodes in the electrochemical cell causes the release of cations at the anode and the simultaneous reduction of water to the group $\mathrm{OH}$ and hydrogen at the cathode. The released metal cations, together with the $\mathrm{OH}$ group, form stable hydroxides that aggregate the pollutant particles from the water, neutralize their charge, and form larger structures with them that are separated by pre-cipitation in solution. Generated hydrogen strengthens the bond between dissolved particles and pollutants, in-creases turbulence in the system and reduces the relative specific gravity of the pollutants (Publication et al., 2015; Orescanin et al., 2018).

$$
\begin{aligned}
& \text { Anode: } \\
& \mathrm{Fe} \rightarrow \mathrm{Fe}^{2+}+2 \mathrm{e}^{-} \\
& 2 \mathrm{H}_{2} \mathrm{O} \rightarrow \mathrm{O}_{2} \uparrow+4 \mathrm{H}^{+}+4 \mathrm{e}^{-}
\end{aligned}
$$

\section{Chatode:}

$$
2 \mathrm{H}_{2} \mathrm{O}+2 \mathrm{e}^{-} \rightarrow \mathrm{H}_{2} \uparrow+2 \mathrm{OH}^{-}
$$


Electroreduction:

$$
\mathrm{Cr}^{6+}+3 \mathrm{Fe}^{2+} \rightarrow \mathrm{Cr}^{3+}+3 \mathrm{Fe}^{3+}
$$

Precipitation:

$$
\begin{aligned}
& \mathrm{Cr}^{3+}+3 \mathrm{OH}^{-} \rightarrow \mathrm{Cr}(\mathrm{OH})_{3} \downarrow \\
& \mathrm{Fe}^{3+}+3 \mathrm{OH}^{-} \rightarrow \mathrm{Fe}(\mathrm{OH})_{3} \downarrow \\
& \mathrm{Fe}^{2+}+2 \mathrm{OH}^{-} \rightarrow \mathrm{Fe}(\mathrm{OH})_{2} \downarrow
\end{aligned}
$$

\section{EXPERIMENTAL WORK}

\subsection{Sampling and preparation of oily water}

Wastewater is collected in an oil and grease separator designed to treat stormwater from traffic areas (public roads and parking lots). Two cleaning series were performed with low load at low currents (15 A). The second series of tests was performed with higher wastewater load and at higher currents (100 A). The wastewater contained in the IBC tank is also contaminated with oily wastewater. The properties of the wastewater before and after the additional load are shown in Table 1.

Table 1. Characteristics of oily wastewater

\begin{tabular}{|l|l|c|}
\hline Parameter & $\begin{array}{c}\text { Wastewater from oil } \\
\text { and grease separators }\end{array}$ & $\begin{array}{c}\text { Wastewater after } \\
\text { additional }\end{array}$ \\
\hline $\mathrm{pH}$ & 6.97 & 6.98 \\
\hline Electrical conductivity - EC $(\mu \mathrm{S} / \mathrm{cm})$ & 599.5 & 583 \\
\hline Dissolved oxygen - DO $(\mathrm{mg} / \mathrm{L})$ & 2.23 & 3.68 \\
\hline Mineral oil $(\mathrm{mg} / \mathrm{L})$ & 3.955 & 129.17 \\
\hline Chemical oxygen demand - COD $(\mathrm{mg} / \mathrm{L})$ & 420 & 1080 \\
\hline
\end{tabular}

\subsection{Equipment and measuring instruments}

The first series of experiments concerned the efficiency of the EAOP / EC process at currents of 15 A. The efficiency of stainless steel (SS), iron (Fe) and aluminium (Al) electrodes was tested. The set of stainless-steel electrodes consisted of 12 electrodes (6 pairs), rectangular ( $400 \times 40 \mathrm{~mm}$ ), active surface $146.7 \mathrm{~cm}^{2}$, electrodes arranged in parallel, separated by a $10 \mathrm{~mm}$ thick insulator (pair $4.5 \mathrm{~mm}$ ), $2 \mathrm{~mm}$ thick. Both sides of the electrodes represent the active surface. Each odd plate was connected as the cathode and the even plate as the anode. The Fe and $\mathrm{Al}$ electrodes had the same dimensions as the stainless-steel electrodes, while the distance between them was $5 \mathrm{~mm}$. The thickness of the iron electrode was $3 \mathrm{~mm}$ and that of the aluminium electrode was $7 \mathrm{~mm}$. Each set of electrodes was placed on the bottom of the reaction vessel and connected to a laboratory rectifier. A MC Power LBN-1990 laboratory rectifier was used to test the treatment efficiency at low currents, while the Mean Well RSP3000-12 was used for higher currents. In all experiments, wastewater was mixed with air using a TetraTec APS 400 pump. Electrical conductivity, $\mathrm{pH}$, dissolved oxygen, and temperature were determined using a Hanna Instruments HI98194 multiparameter probe. Concentrations of mineral oil were deter-mined using a Nexis GC2030 Shimadzu, with samples previously prepared by extraction. Concentrations of heavy metals were determined using an Agilent 5900 ICP-OES instrument.

\subsection{Methodology}

Homogeneity of the sample was achieved by mixing the effluent before taking the sample for the experiments. All experiments were performed in batches in a plastic reaction vessel (reactor). For the analyzes and laboratory tests of the low flow treatment, $10 \mathrm{dm} 3$ of wastewater was taken. The efficiency of stainless steel (SS), iron (Fe) and aluminum (Al) electrodes was tested. The prepared oily wastewater was treated with $15 \mathrm{~A}$ and $21.9 \mathrm{~V}$ on stainless steel electrodes for 30 minutes; then a sample was taken. This is followed by 15 minutes of treatment at $15 \mathrm{~A}$ and $55.6 \mathrm{~V}$ on iron electrodes; then a sample is taken. This is followed by a 15-minute treatment with $15 \mathrm{~A}$, 45.3 V aluminum electrodes: and sampling. After completion of the EAOP treatment, the effluent was gently agitated with air for the next 40 minutes. The effluent was then precipitated and sampled for analysis. In the second 
series of experiments, the efficiency of the same electrode materials with prior pretreatment was investigated. 40 $\mathrm{dm} 3$ of wastewater was placed in two plastic containers. To each plastic container, $60 \mathrm{~g}$ of $\mathrm{NaCl}$ was added to obtain enough conductive ions for the current prescribed in the experiments and enough chloride for the generation of chlorine and hypochlorite. Then, both plastic containers were treated simultaneously with iron electrodes for 10 minutes, container $1(18 \mathrm{~A}, 13.7 \mathrm{~V})$ and container $2(22 \mathrm{~A}, 13.7 \mathrm{~V})$. This was followed by precipitation for 20 minutes and decantation of the wastewater from tanks 1 and 2 into tank 3 until a volume of $40 \mathrm{dm} 3$ was obtained. The wastewater thus prepared was then treated with stainless steel electrodes for 45 minutes. A sample was taken every 15 minutes and the current was measured. Thus, after 15 minutes of treatment, $110 \mathrm{~A}, 13.7 \mathrm{~V}$ was measured; after 30 minutes, $120 \mathrm{~A}, 13.7 \mathrm{~V}$; after 45 minutes, $130 \mathrm{~A}, 13.7 \mathrm{~V}$. This was followed by 30 minutes of treatment with $35 \mathrm{~A}, 13.7 \mathrm{~V}$ iron electrodes and sampling. In the final stage of processing, aluminum electrodes were applied at $35 \mathrm{~A}, 13.7 \mathrm{~V}$.

\section{RESULTS}

\subsection{Wastewater from oil and grease separators}

The wastewater samples were stored in $1 \mathrm{~m} 3 \mathrm{IBC}$ tanks at room temperature $22{ }^{\circ} \mathrm{C}-23{ }^{\circ} \mathrm{C}$. The oily wastewater was slightly contaminated with mineral oil, organic matter, and heavy metals. The values of physico-chemical parameters are given in Table 2. The input sample is colorless, odorless and has neutral $\mathrm{pH}$ (about $\mathrm{pH}$ 6). High levels of COD $(420 \mathrm{mg} / \mathrm{L})$ and mineral oils or total carbon $(4 \mathrm{mg} / \mathrm{L})$ were measured in the input sample. All heavy metal concentrations in the input wastewater were negligible $(\mathrm{ng} / \mathrm{L})$, while the iron concentration was slightly higher $(0.21 \mathrm{mg} / \mathrm{L})$.

Table 2. Physico-chemical parameters in wastewater from oil and grease separators before and after treatment with electrodes made of stainless steel (SS), iron (Fe), aluminum (Al) and after aeration with air

\begin{tabular}{|c|c|l|l|l|c|}
\hline Parameter & $\begin{array}{c}\text { Initial } \\
\text { effluent }\end{array}$ & SS 30 min & Fe 15 min & Al 20 min & $\begin{array}{c}\text { Aeration } \\
40 \text { min }\end{array}$ \\
\hline $\mathrm{pH}$ & 6.97 & 7.36 & 8.59 & 8.2 & - \\
\hline $\mathrm{DO}(\mathrm{mg} / \mathrm{L})$ & 2.23 & 5.5 & 3.45 & 2.68 & - \\
\hline $\begin{array}{c}\mathrm{EC} \\
(\mu \mathrm{S} / \mathrm{cm})\end{array}$ & 599.5 & 466.3 & 356 & 245.6 & - \\
\hline $\begin{array}{c}\mathrm{COD} \\
(\mathrm{mg} / \mathrm{L})\end{array}$ & 420 & 210 & 190 & 200 & 210 \\
\hline $\begin{array}{c}\mathrm{Min} / \mathrm{ral} \text { oil } \\
(\mathrm{mg} / \mathrm{L})\end{array}$ & 4 & 2.8888 & 1.6 & 2.22 & 1.088 \\
\hline $\mathrm{Cd}(\mathrm{ng} / \mathrm{L})$ & 2.552 & 26.60 & 1.267 & 21.35 & 4.097 \\
\hline $\mathrm{Cr}(\mathrm{ng} / \mathrm{L})$ & 2272 & 91444 & 531.1 & 279.5 & 1705 \\
\hline $\mathrm{Cu}(\mathrm{ng} / \mathrm{L})$ & 675.0 & 4702 & $<0.1$ & 1565 & 693.5 \\
\hline $\mathrm{Fe}(\mathrm{ng} / \mathrm{L})$ & 205164 & 843176 & 335534 & 73963 & 202934 \\
\hline $\mathrm{Ni}(\mathrm{ng} / \mathrm{L})$ & 108.8 & 31115 & 183.1 & $<0.1$ & 1259 \\
\hline $\mathrm{Pb}(\mathrm{ng} / \mathrm{L})$ & 112.6 & 1239 & 78.62 & 570.9 & 459.4 \\
\hline $\mathrm{Sn}(\mathrm{ng} / \mathrm{L})$ & 27,48 & 131.5 & 24.91 & 167.8 & 230.7 \\
\hline $\mathrm{Zn}(\mathrm{ng} / \mathrm{L})$ & 2704 & 31280 & $<0.1$ & $<0.1$ & 11618 \\
\hline
\end{tabular}

The combination of stainless steel, iron, and aluminum electrodes has proven effective in removing organic indicators such as COD and mineral oil. When wastewater is electrooxidized with stainless steel electrodes, $\mathrm{Cr}^{6+}$ is formed and the concentration of organic indicators decreases. Chromates released from the sacrificial anode play an important role in the oxidation of the organic load. The ionic form of $\mathrm{Cr}^{6+}$ is a very soluble and toxic form of chromium and must be reduced to the more stable $\mathrm{Cr}^{3+}$. During wastewater treatment with iron electrodes, excess $\mathrm{Cr}^{6+}$ is reduced to $\mathrm{Cr}^{3+}$ by electrochemically generated $\mathrm{Fe}^{2+}$ and at the same time $\mathrm{Fe}^{2+}$ is oxidized to $\mathrm{Fe}^{3+}$. Water is reduced at the cathode with simultaneous formation of $\mathrm{H}_{2}$ and $\mathrm{OH}$ ions. The reaction of cations and $\mathrm{OH}$ ions produce stable hydroxides and electrochemically generated gasses $\mathrm{H}_{2}$ and $\mathrm{O}_{2}$, which additionally mix the suspension during mechanical stirring to ensure constant contact of the pollutant with the iron flocs. (Orescanin et al., 2018). Everything described follows the reactions described previously in Chapter 3.

Electrocoagulation using aluminum electrodes resulted in a small increase in organic indicators com-pared to the previous phase. The concentrations of heavy metals $\mathrm{Cr}$, Fe and $\mathrm{Ni}$ were further reduced, which is very important when they are present in higher concentrations since electrodes were used in the procedure. After a total treatment 
time of 105 minutes at $15 \mathrm{~A}$, more than $50 \%$ of COD and $73 \%$ of mineral oil were removed. The increased levels of chromium, iron, nickel, and zinc are explained by the electrooxidation of the stainless-steel sacrificial anode, which releases these ions.

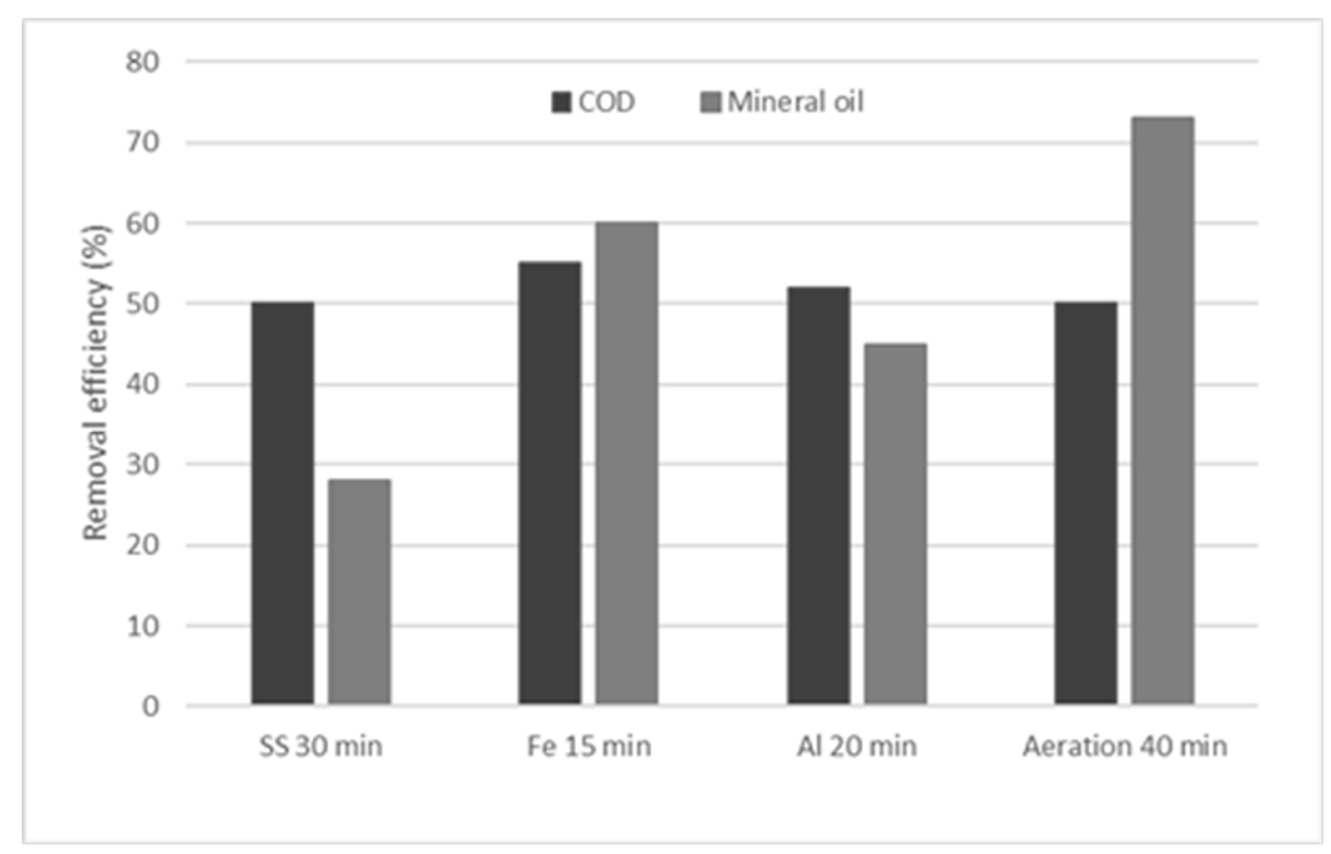

Figure 1. Removal efficiency of COD and mineral oil from wastewater from oil and grease separators during individual stages of treatment using electrodes made of stainless steel (SS), iron (Fe) and aluminum (Al)

\subsection{Additionally loaded wastewater from oil and grease separators}

To conduct studies with higher concentrations of organic loadings, additional loadings were added to the effluent from the previous experiment. $1 \mathrm{~L}$ of used motor oil and $0.5 \mathrm{~L}$ of emulsion from metallurgic processing were added to the wastewater in the IBC tank. The suspension thus prepared was mixed until homogeneous and allowed to stand for 24 hours. Before taking the effluent sample for conducting the experiments, the suspension was well mixed mechanically. The input sample has a neutral $\mathrm{pH}$ (about 6), a dissolved oxygen concentration of $3.68 \mathrm{mg} / \mathrm{L}$, an electrical conductivity of $583 \mathrm{mg} / \mathrm{L}$ and is characterized by an intense odor and a gray-black color. High concentrations of COD $(1080 \mathrm{mg} / \mathrm{L})$ and mineral oils $(129 \mathrm{mg} / \mathrm{L})$ were found. All concentrations of heavy metals in the wastewater were negligible $(\mathrm{ng} / \mathrm{L})$.

Table 3. Physico-chemical parameters in additionally loaded wastewater from oil and grease separators before and after treatment with electrodes made of stainless steel (SS), iron (Fe), aluminum (Al) and after aeration with air

\begin{tabular}{|c|c|c|c|c|c|c|c|}
\hline Parameter & Initial effluent & $\begin{array}{c}\mathrm{SS} \\
15 \mathrm{~min}\end{array}$ & $\begin{array}{c}\mathrm{SS} \\
30 \mathrm{~min}\end{array}$ & $\begin{array}{c}\mathrm{SS} \\
45 \mathrm{~min}\end{array}$ & $\begin{array}{c}\mathrm{Fe} \\
30 \mathrm{~min}\end{array}$ & $\begin{array}{c}\text { Al } \\
30 \mathrm{~min}\end{array}$ & $\begin{array}{c}\text { Aeration } \\
40 \mathrm{~min}\end{array}$ \\
\hline $\mathrm{COD}(\mathrm{mg} / \mathrm{L})$ & 1080 & - & - & - & 243 & - & 43 \\
\hline $\begin{array}{c}\text { Mineral oil } \\
(\mathrm{mg} / \mathrm{L})\end{array}$ & 129.17 & 9.63 & 10 & 7,6 & 15,77 & 13,47 & - \\
\hline $\mathrm{Cd}(\mathrm{ng} / \mathrm{L})$ & 11.68 & 17.70 & $<0.1$ & 22,07 & $<0.1$ & 3,940 & 8,946 \\
\hline $\mathrm{Cr}(\mathrm{ng} / \mathrm{L})$ & 838.1 & 120851 & 386386 & 538297 & 195.3 & 69.79 & 354.4 \\
\hline $\mathrm{Cu}(\mathrm{ng} / \mathrm{L})$ & 539.8 & $<0.1$ & $<0.1$ & $<0.1$ & 77.88 & $<0.1$ & 495.1 \\
\hline $\mathrm{Fe}(\mathrm{ng} / \mathrm{L})$ & 77269 & 36979 & 111353 & 159492 & 17610 & $<0.1$ & $<0.1$ \\
\hline $\mathrm{Ni}(\mathrm{ng} / \mathrm{L})$ & $<0.1$ & 43676 & 62786 & 53402 & 427.9 & 105.3 & 43.10 \\
\hline $\mathrm{Pb}(\mathrm{ng} / \mathrm{L})$ & 583.3 & $<0.1$ & 5.859 & $<0.1$ & $<0.1$ & $<0.1$ & $<0.1$ \\
\hline $\mathrm{Sn}(\mathrm{ng} / \mathrm{L})$ & 526.5 & 263.9 & 290.7 & 98.37 & 331.3 & $<0.1$ & 69.29 \\
\hline $\mathrm{Zn}(\mathrm{ng} / \mathrm{L})$ & 793.4 & $<0.1$ & $<0.1$ & $<0.1$ & $<0.1$ & $<0.1$ & $<0.1$ \\
\hline
\end{tabular}


In the first stage of processing, which includes processing with stainless steel electrodes after 45 minutes of processing, the reduction efficiency of mineral oil was $94 \%$ of tin $80 \%$, while zinc reached $100 \%$ efficiency already in the first 15 minutes. The mechanisms of organic indicator removal by indirect oxidation using electrochemically generated chlorine and hypochlorite formed from chlorides added to wastewater are described in detail in Chapter Two (Orescanin et al., 2018).

In the second phase of treatment, there is a marked increase in the removal efficiency of heavy metals, the concentration of which had increased in the previous phase due to the release of metal ions from the stainless-steel electrode. The chromium and iron removal efficiency were $77 \%$. To remove the yellow color, which came from low molecular weight organics, aluminum electrodes were used in the third phase. The removal efficiency of chromium was $92 \%$ and of tin $100 \%$. After the fourth treatment phase, which included aeration, results of $96 \%$ were obtained COD.

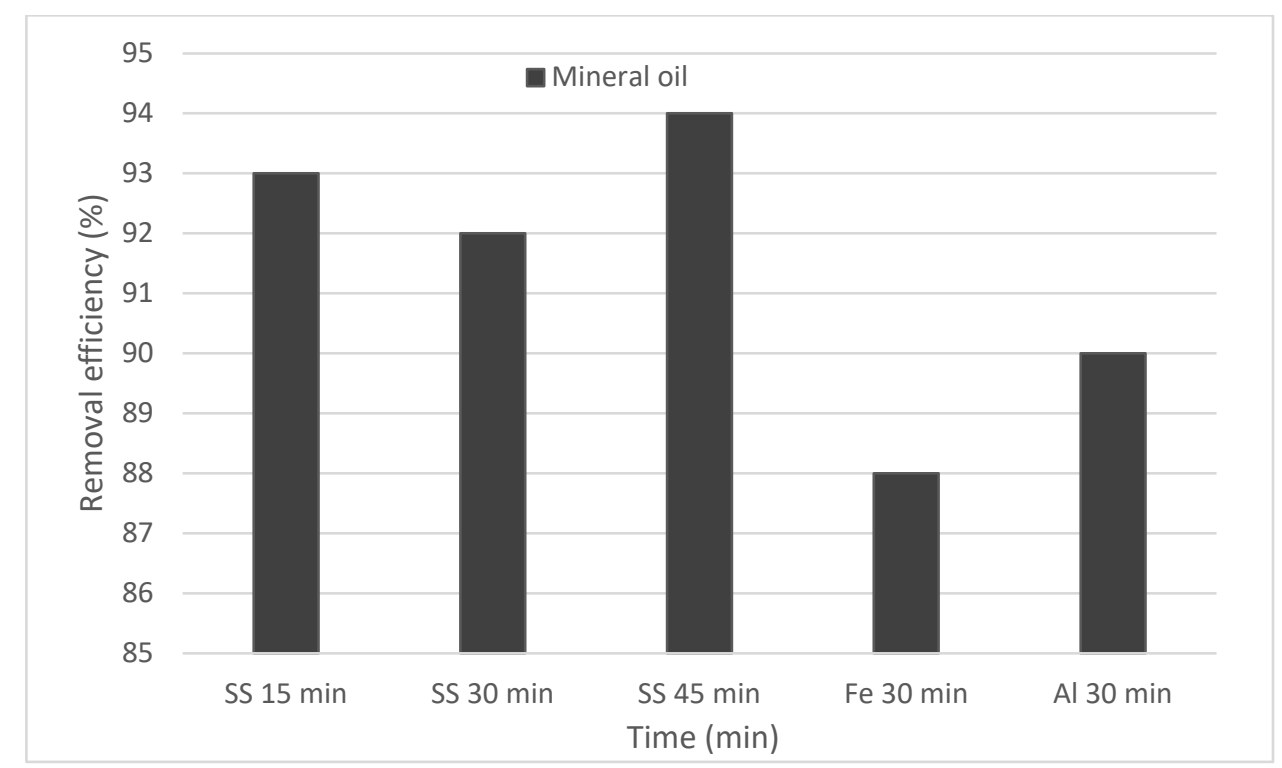

Figure 2. Removal efficiency of mineral oil from wastewater from oil and grease separators additionally loaded with waste oil during individual stages of treatment using electrodes made of stainless steel (SS), iron (Fe) and aluminum (Al)

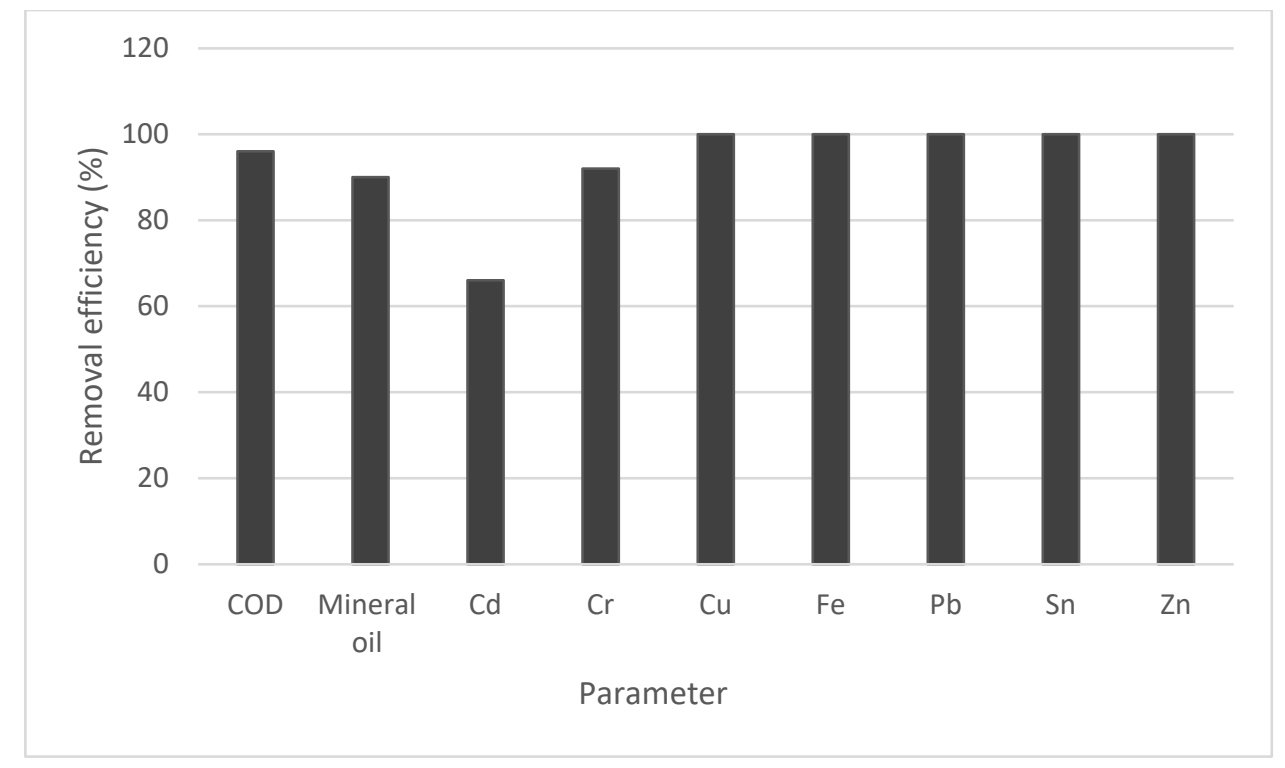

Figure 3. Removal efficiency of COD, mineral oil, and heavy metals after all stages of processing 


\section{CONCLUSION}

The strong development of electrochemistry and the numerous research in this field in the 20th century have led to the increasing importance of electrochemical processes as one of the methods for water treatment. In the last 20 years, with a significant reduction in electricity prices and new ways of generating electricity, these processes have become the subject of numerous scientific studies. In this work, the efficiency of electrochemical advanced oxidation processes is tested on wastewater contaminated with mineral oil. The aim of these experi-ments was to show that these processes can achieve sufficiently good efficiency. In order to confirm the effi-ciency of the method, two series of experiments were carried out.

The wastewater from oil and grease separators used in this work was slightly contaminated with organic indicators (COD), mineral oil, and heavy metals, had no colour, no odour, and the $\mathrm{pH}$ was neutral. The applied current was $15 \mathrm{~A}$ and the efficiencies were $50 \%$ for COD and $73 \%$ for mineral oil.

Used oil and emulsion was additionally added to the wastewater to test efficiency at higher loads.

To achieve the desired current intensity, $60 \mathrm{~g}$ of $\mathrm{NaCl}$ was added to the wastewater. The experiments were carried out at a current of $110 \mathrm{~A}$ and an efficiency of $96 \%$ was obtained for COD and $90 \%$ for mineral oil.

High efficiency in removing heavy metals from this type of wastewater was also confirmed. The values for the removal of cadmium, chromium, copper, iron, lead, tin and zinc were almost $100 \%$.

The method has proven successful in this study and can certainly be a confirmation that the answers to the point pollution issues can be very successful with the development of this technology and with additional application of solar energy sources that needs to be further examined in future research.

Acknowledgments: This work has been fully supported by Croatian Science Foundation under the project "IP2019-04-1169 - Use of treated oily wastewater and sewage sludge in brick industry - production of innovative brick products in the scope of circular economy".

\section{REFERENCES}

Brillas E (2014) Electro-Fenton, UVA Photoelectro-Fenton and Solar Photoelectro-Fenton Treatments of Organics in Waters Using a Boron-Doped Diamond Anode: A Review. J Mex Chem. Soc. DOI:10.29356/jmcs.v58i3.131

Coca Parados J, Gutiérrez G, Benito J (2011) Treatment of oily wastewater. W Puri Manag. DOI:10.1007/97890-481-9775-0_1

Grymonpré DR, Finney WC, Clark RJ, Locke BR (2004) Hybrid gas-liquid electrical discharge reactors for organic com-pound degradation. Ind Eng Chem Res. DOI:org/10.1021/ie030620j

Jurac Z (2009) Otpadne vode. Veleučilište u Karlovcu, Karlovac.

Orescanin V, Kollar R, Nađ K, Ruk D, Halkijević I, Kuspilić M (2018) Elektrokemijska/ultrazvučna/elektromagnetska obrada zrelog odlagališta eluata. Hrv vode.

Orescanin V, Kollar R, Ruk D, Nađ K (2012) Characterization and electrochemical treatment of landfill leachate. Part A, Tox-ic/hazardous substan. \& enviro. Eng. DOI: 10.1080/10934529.2012.646146

Oturan N. and Oturan M.A. (2005) Degradation of three pesticides used in viticulture by electrogenerated Fenton's reagent, Agron. Sustain. Dev. DOI: 10.1051/agro:2005005

Monteil H, Péchaud Y, Oturan N, Oturan MA (2018) A review on Efficiency and Cost Effectiveness of Electro- and Bio-electro-Fenton processes: Application to the Treatment of Pharmaceutical Pollutants in Water. Chem. Eng. J. DOI:org/10.1016/j.cej.2018.07.179

Publication V, Kuokkanen V, Kuokkanen T, Rämö J, Lassi U (2015) Electrocoagulation treatment of peat bog drain-age water containing humic substances. Wat. Res. DOI: 10.1016/j.watres.2015.04.029 